\title{
Is Astrology a Type of Divination? \\ Thomas Aquinas, the Index of Prohibited Books, and the Construction of a Legitimate Astrology in the Middle Ages and the Renaissance ${ }^{1}$ H Darrel Rutkin
}

\author{
Università Ca' Foscari Venezia ${ }^{2}$
}

\begin{abstract}
What is the relationship between astrology and divination? In particular, is astrology a type of divination, as is often asserted or assumed? In both astrology and divination, knowledge and prediction of the future are primary goals, but does this warrant calling astrology a form of divination? I approach these questions by exploring the response of Thomas Aquinas, which was to be extremely influential for many centuries. First I analyze in some detail Thomas's answer in his Summa theologiae 2-2.92-95; then I discuss two significant 16th-century examples of its influence: the 1557, 1559, 1564, and later indexes of prohibited books; and Pope Sixtus V's anti-divinatory bull, Coeli et Terrae Creator (1586). In this way, we can explore some of the complex historical dynamics at play in the construction of a legitimate astrology in the Middle Ages and the Renaissance.
\end{abstract}

Keywords

history of science; history of astrology; Middle Ages; Renaissance; Thomas Aquinas; legitimate knowledge; divination; Index of Prohibited Books

\footnotetext{
${ }^{1}$ A shorter version of this essay, focusing primarily on the material presented here in the first part, was published in an Italian translation as H Darrel Rutkin, "Astrologia e divinazione in Tommaso d'Aquino," trans. Chiara Petrolini, in Il linguaggio dei cieli: Astri e simboli nel Rinascimento, ed. Germana Ernst and Guido Giglioni (Rome: Carocci editore, 2012), 23-37. I treat this material and much more on Thomas Aquinas's discussion of astrology in relation to theology in chapter 5 of H Darrel Rutkin, Sapientia astrologica: Astrology, Magic and Natural Knowledge, ca. 1250-1800, vol. 1, Medieval Structures (1250-1500): Conceptual, Institutional, Socio-Political, TheologicoReligious and Cultural (Dordrecht: Springer, 2019).

${ }^{2}$ I would like to acknowledge that this article was completed as part of a project that has received funding from the European Union's Horizon 2020 Research and Innovation Programme (GA n. 725883 EarlyModernCosmology), as well as support from the University of Sydney while I was an Honorary Associate in History of Science at its School of History and Philosophy of Science.
} 


\section{Introduction}

What is the relationship between astrology and divination? In particular, is astrology a type of divination, as is often asserted or assumed? In this article, I primarily want to make a plea to historicize and particularize these questions by first inquiring about how this relationship was historically understood, rather than simply assuming a particular type of relationship and retrojecting it into the past. ${ }^{3}$ In both astrology and divination, knowledge and prediction of the future are primary goals, but is this sufficient to call astrology a form of divination? When we look at premodern conceptual patterns from a twenty-first-century perspective, many of the nuanced relationships between disciplines lose their distinctive contours, especially if we do so by applying to them the anachronistic concept of the "occult sciences" with its own problematic (especially nineteenth-century) associations. Paying resolute attention to terminology will help us in this endeavor, as will distinguishing between terminological and conceptual anachronism.

I will approach this question by first exploring in some detail the response given by Thomas Aquinas, which was to be extremely influential for many centuries; ${ }^{4}$ then I discuss two significant sixteenth-century examples of its influence. In this way, it becomes possible to explore some of the complex historical dynamics at play in the construction of a legitimate astrology in the Middle Ages and the Renaissance. This material will also provide evidence to help historicize our understanding of the distinction between natural and judicial astrology, whose use is virtually ubiquitous in the scholarly literature but does not always further our understanding.

\footnotetext{
${ }^{3}$ The same is true for the relationship between astrology and magic, which I discuss in relation to the works of Marsilio Ficino and Giovanni Pico della Mirandola in my "The Mysteries of Attraction: Giovanni Pico della Mirandola, Astrology and Desire," Studies in History and Philosophy of Science 41 (2010): 117-24, and my "The Physics and Metaphysics of Talismans (Imagines Astronomicae): A Case Study in (Neo)Platonism, Aristotelianism and the Esoteric Tradition," in Platonismus und Esoterik in Byzantinischem Mittelalter und Italienischer Renaissance, ed. Helmut Seng (Heidelberg, Germany: Universitätsverlag Winter, 2013), 149-73. I will also treat this in much greater detail in H. Darrel Rutkin, Sapientia astrologica: Astrology, Magic and Natural Knowledge, ca. 1250-1800, vol. 2, Renaissance Structures (1450-1500): Continuities and Transformations (Dordrecht: Springer, in progress). As Jean-Patrice Boudet shows so clearly in his magisterial Entre science et nigromance: Astrologie, divination et magie dans l'Occident médiéval, XIIe-XVe siècle (Paris: Publications de la Sorbonne, 2006), divination regularly occurs within the context of both astrology and magic.

${ }^{4}$ There is, of course, a significant history to this discussion, including writings by (among others) Marcus Tullius Cicero, Augustine of Hippo, and Isidore of Seville. For this background and much other relevant information, see Dieter Harmening, Superstitio: Überlieferungs- und theoriegeschichtliche Untersuchungen zur kirchlichtheologischen Aberglaubensgsliteratur des Mittelalters (Berlin: Erich Schmidt Verlag, 1979) and the further literature referenced in the present study, beginning with note 8 .
} 


\section{Thomas Aquinas, Summa theologiae 2-2.92-95}

Astrology is often considered as a form of divination, even today, ${ }^{5}$ but this should be problematized and more precisely historicized. A useful and influential text for doing so is Thomas Aquinas's illuminating and authoritative discussion in Summa theologiae 2-2.92-95, written between January 1271 and Easter 1272, which ultimately became the normative position. ${ }^{6}$ In providing a theological context for understanding superstition and idolatry, Thomas distinguished legitimate and illegitimate modes of knowing and predicting the future, only the latter of which were properly to be called divination (divinatio). In the course of his argument, he clearly explains that what he calls astrologia, which we may neutrally translate as "the science of the stars", in its two main respects-which we both terminologically and conceptually distinguish as "astronomy" and "astrology"-is a perfectly legitimate mode of knowledge. Thomas here sharply distinguishes both parts of astrologia from divinatio, which he goes on to delimit in language clearly reflected in the much later 1557, 1559, 1564, and subsequent indexes of prohibited books, as well as in Pope Sixtus V's anti-astrological (or better, anti-divinatory) bull, Coeli et Terrae Creator (1586), which I will discuss in the second half of this essay. ${ }^{8}$

\footnotetext{
${ }^{5}$ Such as in Roy Willis and Patrick Curry, Astrology, Science and Culture: Pulling Down the Moon (Oxford: Berg, 2004).

${ }^{6}$ For an interesting interpretation of why Thomas wrote the Summa theologiae, see Leonard E. Boyle, "The Setting of the Summa theologiae of Saint Thomas," in Facing History: A Different Saint Thomas (Louvain-la-Neuve, France: Fédération Internationale des Instituts d'Études Médiévales, 2000), 65-91; this chapter was originally published as an independent work, The Setting of the Summa theologiae of Saint Thomas (Toronto: Pontifical Institute of Mediaeval Studies, 1982). For the dating of Thomas's works, see Jean-Pierre Torrell, Saint Thomas Aquinas, Vol. 1, The Person and His Work, trans. Robert Royal (Washington, DC: The Catholic University of America Press, 1996).

${ }^{7}$ In premodern usage from Ptolemy through Thomas and beyond, astronomia and astrologia (whether in Greek, Arabic, Latin, or any of the various vernaculars) were normally used indifferently and interchangeably to refer collectively to both parts of the science of the stars, which we now both terminologically and conceptually distinguish into astronomy and astrology, two disciplines concerned with celestial motions and their influences, respectively. There are, however, some interesting counterexamples to this normal practice, including in Richard of Saint Victor, Pietro d'Abano, and Giovanni Pico della Mirandola, which I discuss in the methodological introduction to Rutkin, Sapientia astrologica, vol. 1, xxv-xxxiii. We should not conclude (as happens too often) that premodern writers either fused or confused the two closely related subdisciplines in any way, shape or form, either conceptually or in practice. For better or worse, most of the confusions that arise are on our side!

${ }^{8}$ The relevant bibliography is vast. Besides Harmening, Superstitio, and Boudet, Entre science et nigromance, the works I have found most useful are: Valerie I. J. Flint, The Rise of Magic in Early Medieval Europe (Princeton: Princeton University Press, 1991) and William E. Klingshirn, "Divination and the Disciplines of Knowledge according to Augustine," in Augustine and the Disciplines: From Cassiciacum to Confessions, ed. Karla Pollmann and Mark Vessey (Oxford: Oxford University Press, 2005), 113-40, and his "Isidore of Seville's Taxonomy of Magicians and Diviners," Traditio 58 (2003): 59-90. For Thomas's views on astrology and astronomy, see Thomas Litt's profound study, Les corps célestes dans l'univers de Saint Thomas d'Aquin (Louvain, Belgium: Publications Universitaires, 1963).
} 
In question 92, article 1, Thomas discusses and defines superstition (superstitio), concluding that "superstition is a vice opposed to religion by excess, not because it offers more divine worship (cultus divinus) than true religion, but rather because it offers divine worship either to something not deserving it, or in an improper manner" (p. 5). ${ }^{9}$ In article 2, Thomas discusses the different species of superstition:

Therefore, the species of superstition can be differentiated, first, with respect to the object (ex parte objecti). Divine worship can be offered to whom it should be offered, namely the true God, but in an improper manner; this is the first species of superstition. Or it can be offered to whom it should not be offered, namely to any creature (cuicumque creaturae). This is another genus of superstition, which is divided into many species corresponding to the different ends (fines) of divine worship: [1] [Idolatry] First, divine worship is oriented to showing reverence to God; accordingly, the first species of this genus is idolatry (idololatria), which offers divine worship undeservedly to a creature [i.e., to something created, not to the Creator Himself]. [2] [Divination] Secondly, divine worship is oriented towards obtaining that which man (homo) learns from God whom he worships. To this belongs divinatory superstition (superstitio divinitiva), which consults demons through certain pacts - tacit or explicit — entered into with them. [3] [Practices] Thirdly, divine worship is oriented toward a certain arrangement of human actions according to God's

\footnotetext{
9 "Sic igitur superstitio est vitium religioni oppositum secundum excessum, non quia plus exhibeat in cultum divinum quam vera religio: sed quia exhibet cultum divinum vel cui non debet, vel eo modo quo non debet" (298b712). I use the readily available bilingual Blackfriars edition as the basis for my often significantly modified translation, Thomas Aquinas, Summa theologiae: Latin Text and English Translation, Introductions, Notes, Appendices and Glossaries, vol. 40, Superstition and Irreverence, trans. and ed. Thomas Franklin O'Meara and Michael John Duffy (London: Blackfriars, 1968), 1-69. I cite the Latin from Thomas Aquinas, Opera omnia, vol. 9 (Rome: Ex Typographia Polyglotta S.C. de Propaganda Fide, 1897), 298-322. Text references are to page, column (with "a" and "b" distinguishing the left and right columns), and line number, beginning with line 1 at the top of each column. For more on the fundamental concept of superstitio, in addition to Harmening, Superstitio, see Edward Peters, The Magician, The Witch, and the Law (Philadelphia: University of Pennsylvania Press, 1978) and his "The Medieval Church and State on Superstition, Magic and Witchcraft: From Augustine to the Sixteenth Century," in Witchcraft and Magic in Europe: The Middle Ages, ed. Bengt Ankarloo and Stuart Clark (Philadelphia: University of Pennsylvania Press, 2002), 173-245. All translations are mine unless otherwise noted.
} 
prescriptions, whom we worship. To this belongs the superstition of certain practices (observationes). (pp. 7-9) ${ }^{10}$

The ends toward which they are aimed - the final causes - thus differentiate the species of this genus.

Of these three types of superstition, the second subdivision, superstitio divinitiva, is our principal concern, which Thomas specifies further immediately below: "Some divinations [2] and practices [3] belong to superstition, to the extent that they depend on some works of demons (operationes daemonum), and thus require compacts made with them (9)."11 For Thomas, then, the pact with demons is a decisive criterion for characterizing superstition and thus a practice's legitimacy. Demons will be discussed more fully below.

Question 95 on superstitio divinitiva examines a wide range of divinatory practices, including those through dreams, demons, augury, the stars, and the casting of lots. ${ }^{12}$ Articles 1 and 5 of this question are of great interest here, in that Thomas explicitly and in detail shows astrology's legitimacy as a form of knowledge and why it deserves that role. Article 1 addresses whether divination is a sin (utrum divinatio sit peccatum). Thomas's response is illuminating:

I respond by saying that by the term divinatio is understood a certain foretelling of future things (quaedam praenuntiatio futurorum). Moreover, future things can be foreknown (praenosci possunt) in two ways: in one way, in their causes (in suis causis); in the other, in themselves (in seipsis). The causes of future things are threefold. [1] Some necessarily and always (ex

\footnotetext{
10 "Diversificatur ergo superstitionis species, primo quidem, ex parte objecti. Potest enim divinus cultus exhiberi vel cui exhibendus est, scilicet Deo vero, modo tamen indebito: et haec est prima superstitionis species. Vel ei cui non debet exhiberi, scilicet cuicumque creaturae. Et hoc est aliud superstitionis genus, quod in multas species dividitur, secundum diversos fines divini cultus. Ordinatur enim, primo, divinus cultus ad reverentiam Deo exhibendam. Et secundum hoc, prima species huius generis est idololatria, quae divinam reverentiam indebite exhibet creaturae. Secundo, ordinatur ad hoc quod homo instruatur a Deo, quem colit. Et ad hoc pertinet superstitio divinitiva, quae daemones consulit per aliqua pacta cum eis inita, tacita vel expressa. Tertio, ordinatur divinus cultus ad quandam directionem humanorum actuum secundum instituta Dei, qui colitur. Et ad hoc pertinet superstitio quarundam observationum" (299a31-b11).

11 "Ad secundum dicendum quod divinationes et observationes aliquae pertinent ad superstitionem inquantum dependent ex aliquibus operationibus daemonum. Et sic pertinent ad quaedam pacta cum ipsis inita" (299b28-32).

${ }^{12}$ For the range of divinatory practices, see Harmening, Superstitio, 178-216.
} 
necessitate et semper) produce their effects. Future effects of this sort can be foreknown and foretold with certainty (per certitudinem praenosci possunt et praenuntiari) from the consideration of their causes: as when astrologi predict future eclipses. [2] But some causes produce their effects not necessarily and always (non ex necessitate et semper), but in most cases (in pluribus), and rarely fail. From such causes their future effects can be foreknown, not with certainty (non ... per certitudinem) but by some conjecture (per quandam conjecturam), as when astrologi, by considering the stars, are able to foreknow and forecast some things (quaedam) about rains or droughts; and physicians (medici) about health or death. (pp. 37, 39) $)^{13}$

Thomas here discusses what can causally (and thus legitimately) be foreknown and foretold. $\mathrm{He}$ distinguishes two modes. In the first, causes always and necessarily produce their effects, which can thus be foreknown and foretold with certainty. In the second, causes only produce their effects for the most part, that is, in the normal course of nature. Effects of such causes too can be foreknown and foretold, but only conjecturally, that is, with a certain probability. Regardless of the degree of certainty, then, both are perfectly legitimate modes of predicting the future because the foreknowing and foretelling are done by means of causal knowledge.

Thomas's examples are extremely informative. In the first, astrologi predict eclipses with certainty from causes that always and necessarily produce the same effects. Astrologi here should be translated "astronomers," as here it is the study of the planetary motions and their prediction that is at issue. In the second case, astrologi (once again) make predictions about rains and droughts, namely weather phenomena, but since the relevant causes do not always and necessarily produce the same effects, the predictions can only be probable. Here astrologi are to

\footnotetext{
13 "Respondeo dicendum quod in nomine divinationis intelligitur quaedam praenuntiatio futurorum. Futura autem dupliciter praenosci possunt: uno quidem modo, in suis causis; alio modo, in seipsis. Causae autem futurorum tripliciter se habent. [1] Quaedam enim producunt ex necessitate et semper suos effectus. Et huiusmodi effectus futuri per certitudinem praenosci possunt et praenuntiari ex consideratione suarum causarum: sicut astrologi praenuntiant eclipses futuras. [2] Quaedam vero causae producunt suos effectus non ex necessitate et semper, sed ut in pluribus, raro tamen deficiunt. Et per huiusmodi causas possunt praenosci futuri effectus, non quidem per certitudinem, sed per quandam conjecturam: sicut astrologi per considerationem stellarum quaedam praenoscere et praenuntiare possunt de pluviis et siccitatibus, et medici de sanitate vel morte" (311a27-b9).
} 
be understood as "astrologers" with their annual revolutions that predict celestial influences on the world at large and in particular regions. ${ }^{14}$

In Tetrabiblos 1.1, Ptolemy made the very same conceptual distinction within the science of the stars (astronomia) between astronomy and astrology with respect to certainty vs. conjecture, where astronomy is an exact science and astrology conjectural. In Tetrabiblos 1.2-3, Ptolemy also discussed why, although it is not an exact science, astrology remains useful, comparing astrology and medicine, which are both identified explicitly as conjectural sciences. ${ }^{15}$ Although Thomas uses the same term, astrologi, to refer to both types of practitioners, he refers here to two different sets of practices that he distinguishes conceptually but not terminologically. ${ }^{16}$

Thomas then draws a telling contrast:

[3] But there are some causes which, if they are considered in themselves (secundum se), can go either way (ad utrumlibet). This is the case particularly (a) with rational powers (potentiae rationales) which are poised before opposites, according to Aristotle. ${ }^{17}$ And such effects, or also (b) if any effects come about by chance in few cases (in paucioribus casu accidunt) ${ }^{18}$ from natural causes (ex naturalibus causis), they cannot be foreknown by considering causes because their causes do not have a determinate inclination (inclinatio determinata) toward such effects. Consequently, these effects

\footnotetext{
${ }^{14}$ Revolutions are one of the four canonical types of astrological practice, along with nativities, elections, and interrogations. For descriptions of each type, see Charles Burnett, "Astrology," in Medieval Latin: An Introduction and Bibliographical Guide, ed. F.A.C. Mantello and A.G. Rigg (Washington, D.C.: Catholic University of America Press, 1996), 369-82; Keith Thomas, Religion and the Decline of Magic (New York: Scribners, 1971), esp. 286-87, and, in more detail, Giuseppe Bezza, Arcana mundi: Antologia del pensiero astrologico antico, 2 vols. (Milan: Rizzoli, 1995). I also discuss them in H Darrel Rutkin, "Astrology," in The Cambridge History of Science, Vol. 3 : Early Modern Science, ed. Lorraine Daston and Katharine Park (Cambridge: Cambridge University Press, 2006), 541-61, in H Darrel Rutkin, "How to Accurately Account for Astrology's Marginalization in the History of Science and Culture: The Essential Importance of an Interpretive Framework," in a special issue of Early Science and Medicine edited by Hiro Hirai and Rienk Vermij, 23 (2018): 217-43, and in the excursus to Rutkin, Sapientia astrologica, vol. 1.

15 Jacqueline Feke valuably discusses this material in her Ptolemy's Philosophy: Mathematics as a Way of Life (Princeton, NJ: Princeton University Press, 2018), chap. 8, esp. 168-76.

${ }^{16}$ This misprision between modern and premodern terminology has led to much confusion in the historiography, which I discuss in detail in the methodological introduction to Rutkin, Sapientia astrologica, vol. 1 and in H Darrel Rutkin, "Understanding the History of Astrology Accurately: Methodological Reflections on Terminology and Anachronism," Philosophical Readings 7 (2015): 42-54 (a special issue on astrology edited by Donato Verardi).

${ }^{17}$ Metaphysics IX, 5. The references are all identified in the margins of the Leonine edition and in the footnotes of the Blackfriars edition. I note only the most significant ones here.

${ }^{18}$ In paucioribus here, as opposed to in pluribus from [2] just above.
} 
cannot be foreknown unless they are considered in themselves (in seipsis). ( $\mathrm{p}$. $39)^{19}$

The causal knowledge described in [1] and [2] is thus sharply contrasted with the cases discussed in [3a] and [3b], where knowledge can be gained only from directly considering the effects (not their causes), namely, [a] acts deriving from rational choice, which is the ability to choose between different possibilities (and thus relates to free will), and [b] irregular and infrequent events that come about by chance. Human beings cannot legitimately foreknow or foretell either, because none of them have determinative, and thus knowable, causes. In these two cases, effects can only be known in themselves. This is the second way that future things can be known beforehand.

Thomas goes on to clarify this by sharply distinguishing between God's cognitive abilities and ours.

Moreover, men can consider effects of this sort in themselves only when they are present, as when a man sees Socrates running or walking. But to consider such in themselves before they come to be is proper to God (Dei proprium), who alone in his eternity sees what will be as present ... : whence Isaiah says: "Announce what will come in the future and we will know that you are gods." Therefore, if someone presumes to foreknow or foretell future things of this sort in any manner whatsoever, except with God's revelation (nisi Deo revelante), ${ }^{20}$ he manifestly usurps to himself what is God's. And from this, some are called diviners (divini). Whence Isidore says in the Etymologies: "Men are called diviners as though they are full of God; they pretend to be

\footnotetext{
19 “Quaedam vero causae sunt quae, si secundum se considerentur, se habent ad utrumlibet: quod praecipue videtur de potentiis rationalibus, quae se habent ad opposita, secundum Philosophum. Et tales effectus, vel etiam si qui effectus ut in paucioribus casu accidunt ex naturalibus causis, per considerationem causarum praenosci non possunt: quia eorum causae non habent inclinationem determinatam ad huiusmodi effectus. Et ideo effectus huiusmodi praenosci non possunt nisi in seipsis considerentur" (311b10-20).

${ }^{20}$ Girolamo Savonarola made much of this distinction in his treatise against the astrologers. See Claudio Gigante's informative introduction to his edition of Girolamo Savonarola, Contro gli astrologi (Rome: Salerno Editrice, 2000), $7-23$.
} 
charged with divinity (divinitate plenos) and they forecast the future for men by shrewd fraud." (p. 39; emphases mine $)^{21}$

Here Thomas relates this illegitimate foreknowledge for human beings to the earlier discussion of superstitio, namely, the usurpation by human beings of what is properly God's.

Thomas concludes by discussing the proper use of the term divinatio and evaluating its sinfulness:

Therefore, it is not called "divination" (divinatio) if someone foretells those things that come about [1] by necessity or [2] for the most part, which can be foreknown by human reason (ratio humana [that is, by causal analysis]). Nor is it divination if someone knows other contingent future matters (futura alia contingentia $^{22}$ when God reveals them (Deo revelante). For then he does not divine (divinat), that is, do what is divine (quod divinum est facit), but rather he receives (suscipit) what is divine. It is only called divining (divinare), then, when one usurps to himself in an inappropriate manner (indebito modo) the foretelling of future events. This is considered a sin (peccatum), whence divinatio is always a sin. And because of this, Jerome (Super Michaeam [Comment. in cap. 3, vers. $9 \mathrm{ff}$.]) says that divinatio always has a negative sense. (p. 39) $)^{23}$

\footnotetext{
21 "Homines autem in seipsis huiusmodi effectus considerare possunt solum dum sunt praesentes, sicut cum homo videt Socratem currere vel ambulare. Sed considerare huiusmodi in seipsis antequam fiant, est Dei proprium, qui solus in sua aeternitate videt ea quae futura sunt quasi praesentia, ... unde dicitur Isaiae XLI, Annuntiate quae futura sunt in futurum, et sciemus quoniam dii estis vos. Si quis ergo huiusmodi futura praenoscere aut praenuntiare quocumque modo praesumpserit, nisi Deo revelante, manifeste usurpat sibi quod Dei est. Et ex hoc aliqui divini dicuntur: unde dicit Isidorus, in Libro Etymol: Divini dicti quasi Deo pleni: divinitate enim se plenos simulant, et astutia quadam fraudulentiae hominibus futura conjectant" $(311 \mathrm{~b} 20-36)$. The quote from Isidore is taken from Etymologiae Libri, 8.9.

${ }^{22}$ What can be known about future contingent events is of course a major issue in both scholastic logic and theology; see e.g., Christopher D. Schabel, Theology at Paris, 1316-1345: Peter Aureol and the Problem of Divine Foreknowledge and Future Contingents (Aldershot, UK: Ashgate, 2000), with much further bibliography and relevant historical background.

23 "Divinatio ergo non dicitur si quis praenuntiet ea quae ex necessario eveniunt vel ut in pluribus, quae humana ratione praenosci possunt. Neque etiam si quis futura alia contingentia, Deo revelante, cognoscat: tunc enim non ipse divinat, idest quod divinum est facit, sed magis quod divinum est suscipit. Tunc autem solum dicitur divinare quando sibi indebito modo usurpat praenuntiationem futurorum eventuum. Hoc autem constat esse peccatum. Unde divinatio semper est peccatum. Et propter hoc Hieronymus dicit, super Michaeam, quod divinatio semper in malam partem accipitur" (312a1-13).
} 
Both Thomas's restrictive use of divinatio and the negative evaluation of practices thus designated are crystal clear: foretelling the future from necessary or regular causes or by divine revelation is not divination. Only the inappropriate foretelling of events is divination and a sin. Although he does not identify them as such here, the two types of contingent future matters that can only be known in themselves - namely, those arising from rational choice and by chancebecome central to the description of what will later be called "judicial astrology," which we will return to below. In this first strong statement of Thomas's position (T1), the foretelling of what arises from both rational choice and from chance is associated with divination and thus categorically rejected.

In responding to the second objection quod non, Thomas reiterates this distinction and returns to the demonic dimension:

Ad 2: There are certain arts (artes quaedam) for foreknowing future events which happen necessarily or frequently; this does not belong to divinatio. But for knowing other future events, there are no true arts or disciplines (verae artes seu disciplinae), but they are false and vain (fallaces et vanae), introduced by the deception of demons, as Augustine says in Book XXI of De civitate Dei. (p. 41$)^{24}$

Thomas clarifies precisely why this is so just below (article 2), in addressing the question whether divinatio is a species of superstition:

Accordingly, it belongs to superstition not only when a sacrifice is offered to demons in idolatry, but also when someone takes on the help of demons for doing or knowing something. Now all divination comes about from the activity of demons (operatio daemonum), either because demons are expressly invoked to manifest the future, or because demons impose themselves on these futile searchings into the future in order to entangle the minds of human beings with

\footnotetext{
24 “Ad secundum dicendum quod artes quaedam sunt ad praecognoscendum futuros eventus qui ex necessitate vel frequenter proveniunt, quod ad divinationem non pertinet. Sed ad alios futuros eventus cognoscendos non sunt aliquae verae artes seu disciplinae, sed fallaces et vanae, ex deceptione daemonum introductae; ut dicit Augustinus, in XXI de Civ. Dei” (312b3-10).
} 
vain conceits. ... Moreover, the inquiry after future matters is vain when someone attempts to foreknow the future from a source from which it cannot be foreknown. Clearly, then, divinatio is a species of superstition. (pp. 41, $43)^{25}$

For Thomas, divination - the attempt to foreknow what cannot legitimately be foreknownalways involves demons (whether implicitly or explicitly) and is thus a species of superstition and a sin.

Responding to objection 3, Thomas reiterates his central point that "all divinatio uses the advice and assistance of demons for the foreknowledge of a future event" (p. 43). ${ }^{26}$ Here are his conclusions:

Ad 3: Therefore, it is clear that the genus of divination (genus divinationis) is threefold. The first is by open invocation of demons (per manifestam daemonum invocationem); this belongs to nigromancers (nigromantici). ${ }^{27}$ The second is only by observing the disposition and movement of something else; this belongs to augurs (augures). The third is when we do something in order to make something hidden (aliquid occultum) manifest to us: this belongs to lots (sortes). ${ }^{28}$ Within each of these categories are many subtypes. (p. 47) ${ }^{29}$

Causal knowledge of the future is legitimate and is not to be called divinatio, which has truck with demons and is a sin.

\footnotetext{
25 "Et ideo ad superstitionem pertinet non solum cum sacrificium daemonibus offertur per idololatriam, sed etiam cum aliquis assumit auxilium daemonum ad aliquid faciendum vel cognoscendum. Omnis autem divinatio ex operatione daemonum provenit: vel quia expresse daemones invocantur ad futura manifestanda; vel quia daemones se ingerunt vanis inquisitionibus futurorum, ut mentes hominum implicent vanitate. . . Vana autem inquisitio futurorum est quando aliquis futurum praenoscere tentat unde praenosci non potest. Unde manifestum est quod divinatio species superstitionis est" (313a12-b1).

${ }^{26}$ Omnis divinatio utitur ad praecognitionem futuri eventus aliquo daemonum consilio et auxilio (315a23-25).

${ }^{27}$ For an insightful discussion of the meaning of "necromancy" vis-à-vis "nigromancy," see Charles Burnett, "Talismans: Magic as Science? Necromancy among the Seven Liberal Arts," in Magic and Divination in the Middle Ages: Texts and Techniques in the Islamic and Christian Worlds (Aldershot, UK: Ashgate Variorum, 1996), 1-15. ${ }^{28}$ The Blackfriars translation renders this as "sorcery," which seems to be an extreme choice, although the word "sorcery" does etymologically descend from sors.

29 "Sic igitur patet triplex esse divinationis genus. Quorum primum est per manifestam daemonum invocationem: quod pertinet ad nigromanticos. Secundum autem est per solam considerationem dispositionis vel motus alterius rei: quod pertinet ad augures. Tertium est dum facimus aliquid ut nobis manifestetur aliquid occultum: quod pertinet ad sortes. Sub quolibet autem horum multa continentur, ut patet ex dictis" (316a19-b4).
} 
In question 95, article 5, Thomas directly and extensively addresses our issue of central concern, namely, whether divination using the stars is illicit (utrum divinatio quae fit per astra sit illicita). He begins with a quote from Augustine: "But against this [sc. that astrology is illicit], Augustine says in book 4 of the Confessions: 'I never hesitated to consult those astrologers (planetarios) whom they call mathematici, because they required no sacrifice or prayers to any spirit for divination, which true Christian piety rejects and condemns"” (51). ${ }^{30}$ Even for Augustine, a normally notoriously anti-astrological authority, at least the astrologers required no sacrifices or prayers and thus were not invoking demons. ${ }^{31}$

Thomas then begins his own reply, which I will treat in full, beginning with demons:

I respond, saying that, as already remarked, a demonic act (operatio daemonum) rushes upon divination which derives from false or vain opinion, so that our souls become mazed in vanity and falsehood. Moreover, one uses vain or false opinion if, by considering the stars, he wishes to foreknow future events that cannot be foreknown by their means. Therefore, we should consider what about the future can be foreknown from observing celestial bodies. And, concerning what comes about necessarily, it is obvious that they can be foreknown through consideration of the stars, as astrologi foretell future eclipses. (pp. 51, 53) $)^{32}$

\footnotetext{
30 "Sed contra est quod Augustinus dicit, in IV Confess: Illos planetarios quos mathematicos vocant, consulere non desistebam; quod quasi nullum esset eis sacrificium, et nullae preces ad aliquem spiritum ob divinationem dirigerentur. Quod tamen Christiana et vera pietas expellit et damnat" (328a4-10). The quote from Augustine is taken from Confessions 4.3.4.

${ }^{31}$ In this passage, Augustine recounts his misguided beliefs as a young man attracted to astrology. In later works, Augustine makes it clear that astrology cannot be dissociated from the work of demons (e.g., On Christian Doctrine 2.49-53; The Literal Meaning of Genesis 2.17.37; The City of God 5.7). My thanks to David Juste for his clarifying comments here. Filippo Fantoni (ca. 1530-91) also cites Augustine as a pro-astrological authority in the teaching manuscript for his sixteenth-century course on Ptolemy's Tetrabiblos at the University of Pisa; see my "The Use and Abuse of Ptolemy's Tetrabiblos in Renaissance and Early Modern Europe: Two Case Studies (Giovanni Pico della Mirandola and Filippo Fantoni)," in Ptolemy in Perspective: Use and Criticism of his Work from Antiquity to the Nineteenth Century, ed. Alexander Jones (Dordrecht: Springer, 2010), 135-149, 143.

32 "Respondeo dicendum quod, sicut dictum est, divinationi quae ex opinione falsa vel vana procedit, ingerit se operatio demonis, ut hominum animos implicet vanitati aut falsitati. Vana autem aut falsa opinione utitur si quis ex consideratione stellarum futura velit praecognoscere quae per ea praecognosci non possunt. Est igitur considerandum quid per caelestium corporum inspectionem de futuris possit praenosci. Et de his quidem quae ex
} 
To clarify his position on what can legitimately be known about the future by considering celestial bodies, Thomas first reiterates the point made earlier in 95.1 concerning what comes about from necessary causes, namely, the prediction of eclipses. He pointedly contrasts this with what can be derived from false and vain opinion with demonic assistance.

Thomas now recounts several different positions on the matter, beginning with the view that the stars signify but do not cause:

But concerning the foreknowledge of future events from a consideration of the stars (praecognitio futurorum eventuum ex consideratione stellarum), there have been different opinions: Some have said that the stars signify (significant) rather than do (faciant $)^{33}$ what is foretold from their consideration. But this is unreasonable, for every corporeal sign (corporale signum) is either [a] an effect of that of which it is a sign, as smoke signifies fire, from which it is caused, or [b] it proceeds from the same cause, and thus, when it signifies the cause, by consequence it also signifies the effect, as a rainbow when it signifies fair weather (serenitas), in that its cause is also the cause of fair weather. But, it cannot be said that the dispositions of the celestial bodies and their motions are the effects of future events. Nor again can they be referred [sc. causally (reduci)] to some common higher cause that is corporeal. They can, however, be referred to one common cause, which is divine providence (providentia divina). ${ }^{34}$ But [1] the motions (motus) and locations (situs) of the celestial bodies are arranged (disponuntur) by divine providence by one causal structure (ratio), and [2] the outcomes of future contingents by another, since the former [1] are arranged according to the structure of necessity (secundum rationem

necessitate eveniunt, manifestum est quod per considerationem stellarum possunt praenosci: sicut astrologi praenuntiant eclipses futuras" (320a11-23).

${ }^{33}$ The verb facere here should be understood as a direct reference to the Aristotelian notion of efficient causality, within which Thomas's entire discussion of causal knowledge derived from the stars implicitly operates. I reconstruct this astrologized Aristotelian natural knowledge in detail in the work of Albertus Magnus, Thomas's esteemed teacher, in "Astrology and Magic," in A Companion to Albert the Great: Theology, Philosophy, and the Sciences, ed. Irven M. Resnick (Leiden, Germany: Brill, 2013), 451-505 and in Rutkin, Sapientia astrologica, vol. 1. For Thomas's views, see Litt, Les corps célestes, in numerous places. In particular, one should follow up the references in the Index under s.v. causalité des corps célestes (396) and universalité (405).

${ }^{34}$ I examine Thomas's astrologically inflected understanding of divine providence in Rutkin, Sapientia astrologica, vol. 1, chap. 5 . 
necessitatis), so that they always turn out in the same manner; whereas the latter [2] are arranged according to the structure of contingency (secundum rationem contingentiae) so that they turn our differently (variabiliter contingent). (p. 53) $)^{35}$

Thomas's causal analysis thus removes the possibility that the stars signify without also being causes. ${ }^{36} \mathrm{He}$ also indicates that, although both celestial bodies and contingent events are ultimately arranged by the same common incorporeal superior cause, namely, divine providence, they are, nevertheless, arranged with two significantly different causal structures. The celestial bodies are arranged by divine providence with a necessary and regular causal structure — which thus allows for legitimate foreknowledge and prediction - in contrast to the outcome of future contingent events, which have a strikingly different, non-necessary structure that results in variable outcomes. ${ }^{37}$

Thomas then draws a broader conclusion, relating legitimate foreknowledge to the knowledge of causes. In particular, it must be borne in mind that not everything is caused by celestial bodies:

Whence, it cannot be the case that foreknowledge of the future (praecognitio futurorum) is drawn from an inspection of the stars (sidera) except as effects are foreknown from causes. Moreover, two kinds of effects are withdrawn from the causality of celestial bodies (subtrahuntur causalitati caelestium corporum). The first are all the effects that happen by accident (contingentes

\footnotetext{
35 "Circa praecognitionem vero futurorum eventuum ex consideratione stellarum, diversi diversa dixerunt. Fuerunt enim qui dicerent quod stellae significant potius quam faciant ea quae ex earum consideratione praenuntiantur. Sed hoc irrationabiliter dicitur. Omne enim corporale signum vel est effectus eius cuius est signum, sicut fumus significat ignem, a quo causatur: vel procedit ab eadem causa, et sic, dum significat causam, per consequens significat effectum, sicut iris quandoque significat serenitatem, inquantum causa eius est causa serenitatis. Non autem potest dici quod dispositiones caelestium corporum et motus sint effectus futurorum eventuum. Nec iterum possunt reduci in aliquam superiorem causam communem quae sit corporalis. Possunt autem reduci in unam causam communem quae est providentia divina: sed alia ratione disponuntur a divina providentia motus et situs caelestium corporum, et alia ratione eventus contingentium futurorum; quia illa disponuntur secundum rationem necessitatis, ut semper eodem modo proveniant; haec autem secundum rationem contingentiae, ut variabiliter contingant" (320a2347).

${ }^{36}$ For a useful analysis of some of the epistemological issues concerning this distinction, see Alexander Fidora, "Signs versus Causes? An Epistemological Approach to Prognosis in the Latin Middle Ages," Tópicos, Revista de Filosofia 47 (2014): 9-23.

${ }^{37}$ Pasquale Porro discusses Thomas's views of contingency within this conceptual nexus in his "Lex necessitatis vel contingentiae: Necessità, contingenza e provvidenza nell'universo di Tommaso d'Aquino," Revue des Sciences Philosophiques et Theologiques 96 (2012): 401-49.
} 
per accidens), both in human affairs and in the world of nature, because, as proved in [Aristotle's] Metaphysics, a chance event does not have a cause (ens per accidens non habet causam) and especially a natural one, such as the power (virtus) of celestial bodies. Because what comes to be by accident is not strictly speaking a single entity, as when a boulder falls and a landslide ensues, or as when a man digging a grave finds a treasure; for these occurrences and others of this sort are not one but many simpliciter. Whereas, the operation of nature always finishes at something single, just as it starts from a single principle, namely the form of a natural thing. $(53)^{38}$

In the realm of contingent events, accidents (chance events), whether in human affairs or in nature, do not have single causes with determinative inclinations toward particular effects (as Thomas explained in 95.1); therefore, they cannot be causally foreknown by human beings.

The other type of effects that are not caused by celestial bodies are those resulting from the actions of free will. Here Thomas makes an argument from the nature of the human psyche, as depicted in Aristotle's De anima:

Secondly, acts of free choice (actus liberi arbitrii), which is [sc. a part of] the faculty of will (voluntas) and reason (ratio), are removed from the causality of the celestial bodies. For mind (intellectus) or reason (ratio) is not a body (corpus), nor the act of a bodily organ (actus organi corporei); and consequently, neither is the will (voluntas), which is in the faculty of reason (ratio), as Aristotle shows in De anima book $3 .{ }^{39}$ Moreover, no body can make an impression (imprimere) on an incorporeal thing. Whence it is impossible for

\footnotetext{
38 "Unde non potest esse quod ex inspectione siderum accipiatur praecognitio futurorum nisi sicut ex causis praecognoscuntur effectus. Duplices autem effectus subtrahuntur causalitati caelestium corporum. Primo quidem, omnes effectus per accidens contingentes, sive in rebus humanis sive in rebus naturalibus. Quia, ut probatur in VI Metaphys., ens per accidens non habet causam: et praecipue naturalem, cuiusmodi est virtus caelestium corporum. Quia quod per accidens fit neque est ens proprie neque unum: sicut quod, lapide cadente, fiat terraemotus, vel quod, homine fodiente sepulcrum, inveniatur thesaurus; haec enim, et huiusmodi, non sunt unum, sed simpliciter multa. Operatio autem naturae semper terminatur ad aliquid unum: sicut et procedit ab uno principio, quod est forma rei naturalis" (320a48-b9).

${ }^{39}$ De anima $3.4,429 \mathrm{~b} 4$.
} 
the heavenly bodies to make an impression directly on intellect or will. ${ }^{40}$ To allow that would deny the difference between intellect and sense. (pp. 53, 55) ${ }^{41}$

The heavenly bodies qua bodies, then, cannot directly impress (that is, influence) the intellect and will because these latter belong to the ratio, the rational soul (anima rationalis), and are thus incorporeal. Thomas's arguments here and elsewhere worked to establish medieval safeguards to protect human free will. Marsilio Ficino subverted these and other medieval safeguards in his $D e$ vita libri tres (1489). ${ }^{42}$

Thomas continues, refining his analysis by showing how celestial bodies can act indirectly on the human mind:

Therefore, the celestial bodies cannot per se be the cause of free will acts (causa operum liberi arbitrii). Nevertheless, they can incline a person dispositively to this [sc. rather than that action], inasmuch as they make an impression on the human body, and consequently on the sense powers (in vires sensitivas), which are the acts of bodily organs that incline to human acts. Yet, as Aristotle makes clear in De anima 3 (11) and Ethics 1 (13), since sense powers obey reason (oboediunt ratione), this imposes no necessity on free will, for by [sc. his or her] reason, a human being (homo) can act counter to the inclination of the celestial bodies (contra inclinationem caelestium corporum ... operari). (p. 55$)^{43}$

Thomas here shows that there is no solid celestial causal basis for making predictions about chance events or those dependent on human free will, the two areas isolated in 95.1. There he stated that predictions in these areas do not admit of causal analysis through astrology and are

\footnotetext{
${ }^{40}$ Unde impossibile est quod corpora caelestia directe imprimant in intellectum et voluntatem.

41 "Secundo autem, subtrahuntur causalitati caelestium corporum actus liberi arbitrii, quod est facultas voluntatis et rationis. Intellectus enim, sive ratio, non est corpus nec actus organi corporei; et per consequens nec voluntas, quae est in ratione: ut patet per Philosophum, in III De anima. Nullum autem corpus potest imprimere in rem incorpoream. Unde impossibile est quod corpora caelestia directe imprimant in intellectum et voluntatem: hoc enim esset ponere intellectum non differe a sensu" (320b10-20).

42 I will discuss this in Rutkin, Sapientia astrologica, vol. 2.

43 "Unde corpora caelestia non possunt esse per se causa operum liberi arbitrii. Possunt tamen ad hoc dispositive inclinare, inquantum imprimunt in corpus humanum, et per consequens in vires sensitivas, quae sunt actus corporalium organorum, quae inclinant ad humanos actus. Quia tamen vires sensitivae obediunt rationi, ut patet per Philosophum, in III de Anima et in I Ethic., nulla necessitas ex hoc libero arbitrio imponitur, sed contra inclinationem caelestium corporum homo potest per rationem operari" (320b24-34).
} 
thus divinatory, demonic, and illegitimate (T1). In the last point, concerning the indirect influence of the stars on the mind through their direct influence on the body, however, the strength of Thomas's position begins to modulate, allowing at least some-albeit indirectcelestial influences on the mind and thus on a person's actions. Regardless, astrological determinism is wholly avoided by Thomas's Aristotelian analysis, a fundamental feature of legitimate astrological knowledge and practice. ${ }^{44}$

Thomas's response to the second introductory argument quod non develops this analysis further in addressing how astrologers are able to make true predictions:

Ad 2: That astrologi frequently make true predictions (vera praenuntiant) from consideration of the stars happens in two ways: First, since most people follow their bodily passions, therefore their acts are disposed for the most part according to the inclination of the celestial bodies. But there are few, and these are the wise only (soli sapientes), whose inclinations of this sort are moderated by reason. Therefore, astrologers (astrologi) make many true forecasts, and especially in communal events that depend on a multitude of people. (p. 55) ${ }^{45}$

Celestial bodies thus act directly on human bodies, their organs and their faculties, and thereby indirectly on the rational soul, its intellect and its will. Necessity is thus removed from the equation: the stars incline but do not compel, as the old saying goes. Nevertheless, astrologers often make true predictions because most people follow their bodily passions unmitigated by reason. Here Thomas directly offers support for social and political predictions derived from revolutions or general astrology but also (and perhaps inadvertently) for nativities as well, a position also found in his extremely interesting opusculum, the De operationibus occultis naturae ${ }^{46}$ which was written contemporaneously with this part of the Summa theologiae.

\footnotetext{
${ }^{44}$ Albertus Magnus, Roger Bacon and the deliberately anonymous author of the Speculum astronomiae also discuss astrology at length in relation to determinism and freedom of the will. I treat this fundamental theme in Rutkin, Sapientia astrologica, vol. 1. This issue is discussed in detail in Litt, Les corps célestes, 200-19.

45 "Ad secundum dicendum quod hoc quod astrologi ex consideratione astrorum frequenter vera praenuntiant, contingit dupliciter. Uno quidem modo, quia plures hominum passiones corporales sequuntur, et ideo actus eorum disponuntur, ut in pluribus, secundum inclinationem caelestium corporum: pauci autem sunt, idest soli sapientes, qui ratione huiusmodi inclinationes moderentur. Et ideo astrologi in multis vera praenuntiant: et praecipue in communibus eventibus, qui dependent ex multitudine" (320b47-321a2).

${ }^{46}$ I discuss this latter text in Rutkin, Sapientia astrologica, vol. 1.
} 
Thomas concludes

Therefore, if anyone uses a consideration of the stars to foreknow future chance or fortuitous events, or also to know with certainty (per certitudinem) the future works (opera) of men, this proceeds from false and vain opinion. Thus, the act of a demon (operatio daemonis) is mixed in. Whence it will be superstitious and illicit divinatio. But if someone were to use a consideration of the stars to foreknow future things caused by celestial bodies-for instance, droughts and rainfall and other things of this sort-it will be neither illicit nor superstitious divination. ${ }^{47}$ (p. \#)

Here Thomas offers a more nuanced second statement (T2) of his position concerning the knowledge and prediction of future contingent and chance events and those dependent on free will.

In both statements of his position, Thomas is clear and largely consistent: using causal analysis, whether exact or conjectural, human beings can to varying degrees foreknow and foretell the future by observing the stars. The two statements are not as consistent, however, concerning the more controversial prediction of future contingent events, whether accidental and irregular, or of actions deriving from free will. In the first, stronger statement (95.1 [T1]), Thomas relegates predictions on all of these matters to divination and illegitimacy, saying that there is no causal basis whatsoever for foreknowledge or prediction of such events. In his second, modified statement (95.5 ad 2 [T2]), however, Thomas seems to restrict this strong position to accidental events alone. For actions dependent on the choice exercised by a free will, on the other hand, Thomas opens the door to legitimate foreknowledge and prediction, but only of a conjectural nature. The key phrase here is per certitudinem, a certainty caveat, which in $\mathrm{T} 2$ seems clearly to have application only to predictions of acts dependent on free will, due to the stars' direct action on the body and thereby their indirect action on the mind.

\footnotetext{
47 "Si quis ergo consideratione astrorum utatur ad praecognoscendos futuros casuales vel fortuitos eventus, aut etiam ad cognoscendum per certitudinem futura opera hominum, procedet hoc ex falsa et vana opinione. Et sic operatio daemonis se immiscet. Unde erit divinatio superstitiosa et illicita. Si vero aliquis utatur consideratione astrorum ad praecognoscendum futura quae ex caelestibus causantur corporibus, puta siccitates et pluvias et alia huiusmodi, non erit illicita divinatio nec superstiosa" (320b35-45).
} 
Both of Thomas's positions are clearly reflected in the sixteenth-century material to be discussed below. Rule IX of the Index of Prohibited Books (1564) follows Thomas's second, more tolerant, position (T2), while Sixtus V's bull Coeli et terrae creator (1586) follows the more restrictive first statement (T1). Both sixteenth-century texts thus find implicit support in Thomas's much earlier work, although neither cites Thomas explicitly to support their respective positions. ${ }^{48}$ I should also note that the terms natural and judicial astrology do not occur in Thomas's passages discussed here. In sum, for Thomas, astronomy and astrology are legitimate disciplines for knowing about and predicting the future if practiced within their proper limitations. Needless to say, negotiating these boundaries could prove to be tricky. All of these central themes will recur in what follows as we now turn to explore significant features of the theologico-juridical influence of Thomas's views on these matters. ${ }^{49}$

\section{Rule IX of the Index of Prohibited Books}

Promulgated by the bishops soon after the Council of Trent had been dispersed, the official Index of Prohibited Books (1564) explicitly discussed astrology vis-à-vis divination, especially in Rule IX, which, in its entirety, reads as follows: ${ }^{50}$

$$
\begin{aligned}
& \text { Rule IX. }[\mathrm{I}]^{51} \text { All books and writings of geomancy, hydromancy, aeromancy, } \\
& \text { pyromancy, onomancy, chiromancy and necromancy, or all books and writings }
\end{aligned}
$$

\footnotetext{
${ }^{48}$ Both sixteenth-century positions also appear in the wake of Giovanni Pico della Mirandola's extensive and influential Disputationes adversus astrologiam divinatricem, which was composed in 1493-94, and published posthumously in 1496. In it, Pico vigorously attempts to rebrand all of astrology as divination, thus collapsing Thomas's careful distinctions. I discuss this in my “Optimus malorum: Giovanni Pico della Mirandola's Complex and Highly Interested Use of Ptolemy in the Disputationes adversus astrologiam divinatricem (1496), A Preliminary Survey," Presented at the Conference Ptolemaeus Arabus et Latinus, London, November 2015, and much more fully in Rutkin, Sapientia astrologica, vol. 2.

${ }^{49}$ In the very next question (II-II.96), Thomas discusses imagines astronomicae or talismans, which we would call a magical or operative branch of astrology. For a wide-ranging and profound study of this topic through ca. 1500, see Nicolas Weill-Parot, "Les images astrologiques" au moyen âge et à renaissance: spéculations intellectuelles et pratiques magiques (XIIe-Xve siècle) (Paris: Champion, 2002).

${ }^{50}$ I transcribe this text from the facsimile reproduction of the official text published by Paolo Manuzio in Rome in the magnificent edition, Index des livres interdits (ILI), vol. VIII, Index de Rome 1557, 1559, 1564: Les premiers index romains et l'index du concile de Trente, ed. J. M. De Bujanda (Sherbrooke, Québec: Centre d'études de la Renaissance, 1990), 818. For a detailed discussion of the circumstances surrounding the composition, publication and promulgation of the Indexes described here, see ILI, vols. VIII and IX, and Paul F. Grendler, The Roman Inquisition and the Venetian Press, 1540-1605 (Princeton: Princeton University Press, 1977), in both of which one may find a discussion of how the introductory rules function.

${ }^{51}$ I use this numeration below in a comparison of the text of Rule IX to that of Sixtus V's bull.
} 
in which sortilegia, veneficia, auguria, auspicia, or incantations of the magical art are contained, are completely rejected. ${ }^{52}$

In the first part of Rule IX, various forms of divination are completely rejected, along with other practices. ${ }^{53}$ Astrology is not mentioned.

The crucial part explicitly addressing astrology follows:

[II][A] But Bishops should diligently see that books, treatises and indices of judicial astrology (astrologia iudiciaria) not be read or owned, which dare to affirm that something either of [1] future contingent outcomes (de futuris contingentibus successibus), or [2] chance occurrences (fortuitisve casibus), or [3] those actions which depend on human volition (iis actionibus, quae ab humana voluntate pendent), will turn out with certainty (certo). [B] But judgments (iudicia) and natural observations (naturales observationes) which have been written to assist in navigation, agriculture or the art of medicine are permitted. $^{54}$

As Rule IX makes perfectly clear, the crucial issue in the first astrological part-concerning what is explicitly called "judicial astrology" [IIA] - is the certainty of prediction regarding three types of circumstances: [1] future contingent or [2] chance events, and [3] actions dependent on human free will, precisely the domain that Thomas isolated in Summa theologiae 2-2.95.1, 5 as discussed above. In his modified second position (T2), Thomas's caveat "with certainty" seems clearly to refer there only to the results of human actions that are dependent on free will, but not to what he describes as future fortuitous or chance events. Rule IX, however, applies the certainty caveat to all three, thus significantly expanding astrology's legitimate domain. If a prediction about the controversial areas now explicitly called judicial astrology is not made with

\footnotetext{
52 "Regula Nona. Libri omnes, et scripta Geomantiae, Hydromantiae, Aeromantiae, Pyromantiae, Onomantiae, Chiromantiae, Necromantiae, sive in quibus continentur Sortilegia, Veneficia, Auguria, Auspicia, Incantationes artis Magicae, prorsus reiiciuntur."

${ }^{53}$ For these illicit practices, many of which were also discussed by Thomas, see Harmening, Superstitio.

54 " [A] Episcopi vero diligenter provideant, ne Astrologiae iudiciariae libri, tractatus, indices legantur, vel habeantur, qui de futuris contingentibus successibus, fortuitisve casibus, aut iis actionibus, quae ab humana voluntate pendent, certo aliquid eventurum affirmare audent. [B] Permittuntur autem iudicia, et naturales observationes, quae navigationis, agriculturae, sive medicinae artis iuvandae gratia conscripta sunt."
} 
certainty, namely, if it regards contingent and chance events and those dependent on the choices of free will, it should not be considered problematic. ${ }^{55}$

A further clarification is added: if the astrological judgments or natural observations were made to aid navigation, agriculture, or medicine, they are expressly permitted. ${ }^{56}$ Although Rule IX does not specify this, it may be seen as an expansion and specification of Thomas's discussion of legitimate certain or conjectural predictions based on causal analysis. In this case, however, in addition to revolutions, the natural observations referred to in the Rule mainly seem to be elections - the branch of practical astrology geared towards choosing astrologically propitious times - as in Thomas's short consultation De iudiciis astrorum, which he composed in the same period as the Secunda Secundae of the Summa theologiae. ${ }^{57}$ In De iudiciis astrorum, he mentions exactly the same three ends as acceptable:

For all human beings use some observation (observatio) of the celestial bodies concerning effects of this sort as [1] farmers (agricole) sow and reap at a specific time (certo tempore) that is observed in accordance with the sun's motion; [2] seamen (naute) avoid sailing (navigationes) at full or new moon; and [3] physicians (medici) observe critical days (creticos dies observant) in relation to illnesses, which are determined according to the course of the sun and moon. ${ }^{58}$

\footnotetext{
${ }^{55}$ Astrology's predictive certainty was precisely the issue in Galileo's first and lesser known brush with the Inquisition (1604), which I discuss in my article, "Galileo Astrologer: Astrology and Mathematical Practice in the Late Sixteenth and Early Seventeenth Centuries," GALILAEANA: Journal of Galilean Studies 2 (2005): 107-43, 126-28. The sources for this study were discovered, published, and discussed by Antonino Poppi in his Cremonini, Galilei e gli inquisitori del santo a Padova (Padua, Italy: Centro Studi Antoniani, 1993).

${ }^{56}$ For the range of premodern uses of observatio, including in the science of the stars, see Katharine Park's penetrating analysis, "Observation in the Margins, 500-1500," in Histories of Scientific Observation, ed. Lorraine Daston and Elizabeth Lunbeck (Chicago: University of Chicago Press, 2011), 15-44.

${ }^{57}$ See Torrell, Saint Thomas Aquinas, 215 and 356.

58 "Nam omnes homines circa huiusmodi effectus aliqua observatione utuntur celestium corporum: sicut agricole seminant et metunt certo tempore quod observatur secundum motum solis; naute navigationes vitant in plenilunio vel in lune defectu; medici circa egritudines creticos dies observant, qui determinantur secundum cursum solis et lune (17-24)." The critical edition of this text is in vol. 43 (1976) of the Leonine Edition, 201. I treat this text more fully in Rutkin, Sapientia astrologica, vol. 1, chap. 5.
} 
In fact, these three ends - navigation, agriculture, and medicine-were often explicitly mentioned together as legitimate uses of astrology over the next two centuries. ${ }^{59}$ Thus, without explicitly saying so, but by using terminology very close to that of our modern distinction, the official 1564 Tridentine Index offers a proto-version of our distinction between natural and judicial astrology, where judicial astrology concerns the foreknowledge and prediction of contingent and chance events and of actions based on human free will; in this discussion, legitimacy turns primarily on claims of certainty in prediction.

We should also note that both judgments and natural observations (or simply observation, as in Thomas's De iudiciis astrorum) are the explicit astrological means used to attain the legitimate natural ends of navigation, agriculture, and medicine. In this case, because the ends are explicitly deemed to be legitimate, both the relevant judgments and natural observations, that is, the astrological means, are, too. It is unfortunate for us, however, that the different practices associated with the two astrological means are not explicitly described. Furthermore, if the troublesome term "judgments" did not appear in the second group, the distinction would be much cleaner to modern eyes. Judgments obviously occur in both the natural and judicial domains, then, which would seem to undermine our seemingly more simplistic dichotomy. In fact, all astrological interpretive practices were normally called judgments (iudicia), at least since the time of the deeply influential Speculum astronomiae (1260s). ${ }^{60}$

\footnotetext{
${ }^{59}$ The latest evidence I know of for this can be found in a 1781 text by Giuseppe Toaldo, who taught astronomy and medicine at the University of Padua from 1763-97. For a fuller discussion, see H. Darrel Rutkin, Sapientia astrologica: Astrology, Magic and Natural Knowledge, ca. 1250-1800, vol. 3, Early Modern Structures (15001800): Continuities and Transformations (Dordrecht: Springer, in progress). In fact, these three ends were a locus classicus already in Antiquity, especially among the Church Fathers and early ecclesiastical authors who had to explain Genesis 1:4 while distancing themselves from astrology (e.g., Augustine, The Literal Meaning of Genesis II.14.29 or Cassiodorus, Institutiones II.7.4, to name just two influential authors). My thanks again to David Juste for this clarification.

${ }^{60}$ The phrase scientia iudiciorum astrorum is used in Chapter 3 of the Speculum astronomiae to describe all astrological practices. For the Latin text, an English translation and an extensive (but not definitive) historiographical study, see Paola Zambelli, The Speculum astronomiae and its Enigma: Astrology, Theology and Science in Albertus Magnus and his Contemporaries (Dordrecht, Germany: Kluwer, 1992). In fact, the author of the Speculum astronomiae only followed what had been common practice since the first half of the twelfth century in the translations of Arabic astrological texts, whose titles read, for example, Liber iudiciorum (astrorum), Iudicia (astrorum) and the like, reflecting the Arabic 'Ilm ahkäm al-nujūm (The Science of the Judgements of the Stars). On the development of the term scientia de iudiciis (astrorum) into the usual name for astrology from the time of the Arabic-Latin translations, see Charles Burnett, "On Judging and Doing in Arabic and Latin Texts on Astrology and Divination," in The Impact of Arabic Sciences in Europe and Asia, ed. Agostino Paravicini Bagliani (Florence: SISMEL-Galluzzo, 2016), 3-11. The term scientia judiciaria seems to have developed later. My thanks go to David Juste and to the anonymous editor for their clarifications here. I also discuss Roger Bacon's related but
} 
The 1564 Index retained part of a passage from the 1557 Roman Index Auctorum et Librorum, which listed books considered problematic and/or confirmed or suspected of heresy by the Roman Inquisition. A comparison of the 1557 version with that of the official 1564 text quoted above is illuminating:

[a] All books and writings of chiromancy, geomancy, hydromancy, physiognomy, pyromancy or necromancy, or those in which sortilegia, veneficia, incantations, magical divinations (magicae divinationes) or [b] astrological judgments (astrologica iudicia) concerning births (geneses), nativities (nativitates), future events (futuri eventus) or particular outcomes (particulares successus) of the status, life or death of any person are described. $^{61}$

In this earlier text, all of what are called astrological judgments — which refer here primarily to nativities - are closely linked with a range of divinatory practices, and all are identified as problematic or condemned.

The 1557 text was already augmented in the 1559 Index:

[a] All books and writings of chiromancy, physiognomy, aeromancy, geomancy, hydromancy, onomancy, pyromancy or necromancy, or in which sortilegia, veneficia, auguria, auruspicia, incantations of magical art or [b] divinations of judicial astrology (astrologiae iudiciariae divinationes) concerning future contingent events, or the outcomes of events, or chance happenings, with only those natural observations excepted which were written for the sake of helping navigation, agriculture or medical art. ${ }^{62}$

different distinction between astronomia iudiciaria and astronomia operativa in Rutkin, Sapientia astrologica, vol. 1.

61 "Libri omnes, et scripta, Chyromantiae, Geomantiae, Hydromantiae, Physonomiae (sic), Pyromantiae, vel Necromantiae, sive in quibus Sortilegia, veneficia, incantationes, Magicae Divinationes, vel Astrologica iudicia, circa Geneses, Nativitates, futuros eventus, sive particulares successus, status, vitae, vel mortis cuiusvis hominis describantur (40).” Printed in facsimile in ILI VIII, 737, no. 072.

62 "[a] Libri omnes, et scripta Chiromantiae, Physionomiae, Aeromantiae, Geomantiae, Hydromantiae, Onomantiae, Pyromantiae, vel Necromantiae, sive in quibus Sortilegia, Veneficia, Auguria, Aurispicia, Incantationes, Magicae 
This text, from 1559, is more differentiated than that of 1557 , and it clearly and explicitly indicates the three legitimate ends of navigation, agriculture, and medicine and the natural observational means allowed to pursue them. This is a much cleaner example of the naturaljudicial distinction, where judicial astrology — concerning future contingent and chance eventsis explicitly lumped in with and called divination, and thus rejected. It is also explicitly contrasted with natural observations, which are all permitted. There is no further complication here by saying that judgments (iudicia) can also be useful means to the three legitimate natural ends.

We can now see that Rule IX of the official 1564 Tridentine Index more carefully organized the first divinatory part of both earlier Indexes [a], and greatly clarified the second astrological part [b], especially in relation to the key issue of certainty's role in legitimate judicial practices, which was not explicitly treated in the earlier texts. It also takes over and complicates the legitimate natural dimension from the 1559 Index. Rule IX of the 1564 Index, which was extremely influential, was restated verbatim in its entirety in the official 1596 Index and in all subsequent editions. Thus in the end, both judicial and natural astrology were expressly permitted by the Roman Inquisition, as expressed in its official documentation, so long as certainty was not claimed, thus following and significantly broadening Thomas's analysis, in particular, the second modified statement of his position at 2-2.95.5 ad 2 (T2).

\section{Coeli et terrae creator (1586)}

The papal bull Coeli et terrae creator is a long and interesting legal document that was promulgated in 1586, during the first full year of Sixtus V's papacy (lived, 1521-90; pope, 1585-90). It casts such a long shadow in the historiography that we should analyze it in some detail. Here, I will only treat the parts that are directly relevant to astrology's legal situation, in particular, the bull's relationship to Rule IX of the Index and to Thomas's discussion of divination in Summa Theologiae 2-2.92-95, both of which provide the primary theologico-legal

artis, vel [b] Astrologiae iudiciariae Divinationes circa futuros contingentes eventus, aut eventuum successus, sive fortuitos casus, iis tantum naturalibus observationibus exceptis, quae Navigationis, Agricolationis, sive Medicae artis iuvandae gratia conscriptae sunt" (ILI VIII, 775, no. 072). 
background against which Sixtus wrote. ${ }^{63}$ We will see that this bull collapses the distinctions made by Thomas and especially Rule IX as it throws judicial astrology altogether into the snake pit of divination and thus of demonic interaction. ${ }^{64}$ Although the bull is certainly antiastrological, as is often remarked, it by no means rejected all of astrology, as we will see. ${ }^{65}$

After a highly rhetorical introduction, Sixtus turns from a general treatment of demons, divination, and damnation to confront astrology directly:

Since this is the case, some people — not attending to these things faithfully and religiously (as they should), but pursuing curious things (curiosa)—offend God profoundly (graviter), erring themselves and sending others into error. In the first rank of these ${ }^{66}$ are the astrologi, ${ }^{67}$ formerly called mathematici, genethliaci, and planetarii, ${ }^{68}$ who, professing the vain and false ${ }^{69}$ science of the constellations and stars (syderum, et astrorum scientia), and bustling about with great audacity that they can anticipate the arrangement of the divine order (divinae dispositionis ordinatio) ${ }^{70}$ to be revealed in its time, they gauge the nativities or genitures of men from the motion of constellations and the course of the stars (hominum nativitates, seu genituras ex motu syderum, et astrorum cursu metiuntur), and they make judgments about future matters (iudicant futura), or even present ones, and past hidden things (praeterita occulta). And

\footnotetext{
${ }^{63}$ See Germana Ernst, "Della Bolla 'Coeli et terrae' all' 'Inscrutabilis': L'astrologia tra religione, natura e politica nell'età della Controriforma," in her Religione, ragione e natura: ricerche su Tommaso Campanella e il tardo Rinascimento (Milan: FrancoAngeli, 1991), 255-79 for a very interesting discussion.

${ }^{64}$ For more on Sixtus V's background as a fierce inquisitor and on his religious affiliation, see Grendler, Roman Inquisition. For an interesting article that sharply contrasts Augustine's position with Thomas's, see Donato Verardi, "Les Enseignements sur l'Astrologie d'Augustin d'Hippone et de Thomas d'Aquin dans la Bulle Coeli et Terrae de Sixte V," Revue des Sciences Philosophiques et Théologiques 101 (2017): 125-33.

${ }^{65}$ This bull is also often used as part of the evidence for a larger "end of astrology" argument that also normally marshals the change in terminology in the mathematics course at the University of Bologna ca. 1570 from astronomia-astrologia to mathematica as evidence. I critique this argument in detail in Rutkin, Sapientia astrologica, vol. 3 .

${ }^{66}$ The grammar of the text seems problematic here, but the sense is crystal clear. This passage also seems to echo Pico's discussion in the Proem to his Disputations, in which he bitingly refers to astrology as the mother of all superstitions. Giovanni Pico della Mirandola, Disputationes adversus astrologiam divinatricem, ed. Eugenio Garin, vol. 1 of 2 (Turin: Nino Aragno, 2004), 38, 28-40, 1.

${ }^{67}$ This is, of course, precisely the term Thomas used to refer to the practitioners of the two types of legitimate causally based foreknowledge using the science of the stars in II-II.92-95, as Sixtus surely knew.

${ }^{68}$ This is Augustine's term, which appears in the above quotation from Thomas at the beginning of 95.1.

${ }^{69}$ This picks up Thomas's expression vanae et fallaces, which he uses three times in the texts discussed above (95.1 ad 2; 95.5; 95.5 ad 2), always referring directly to problematic illegitimate divinatory practices.

${ }^{70}$ Namely, God's providential ordering of the world.
} 
from the birth and natal day of children (ex puerorum ortu, et natali die) or with some other extremely vain observation and noting of times and moments (quavis alia temporum, et momentorum vanissima observatione, et notatione), they rashly presume to foreknow, make judgments and affirmations concerning the status, condition, life's path, honors, wealth, offspring, health, death, journeys, battles, enemies, imprisonments, murders, various decisions, and other prosperous and adverse occurrences and events of any person soever, but not without great danger of error and infidelity. Since Saint Augustine, a leading light of the Church, affirms that he who observes and attends to these things, who receives [them, sc. astrologers] into his home and who asks questions (interrogat [= makes interrogations]) falsely professes the Christian faith and baptism, as the Apostle [Paul] accuses and reproaches them with these words: "You observe days and months and times and years. I fear that perhaps I have labored among you for no reason." (Galatians 4:10-11)

In this richly textured, informative passage, Sixtus mentions an actual divinatory art for the first time, namely, astrology, which he immediately places in the first rank of problematic practices. In discussing predictions made using [1] the time of birth, [2] the observation and noting of times and moments, and [3] the asking of questions, Sixtus refers here to three of the four canonical types of astrological practice, namely, nativities, elections, and interrogations, all of which he

\footnotetext{
71 "Quae cum ita sint, nonnulli haec fideliter, et religiose, ut debent, non attendentes, sed curiosa sectantes, graviter Deum offendunt, errantes ipsi, et alios in errorem mittentes; tales in primi sunt Astrologi olim Mathematici, Genethliaci, et Planetarii vocati, qui vanam, falsamque syderum, et astrorum scientiam profitentes, divinaeque dispositionis ordinationem suo tempore revelandam praevenire audacissime satagentes, hominum nativitates, seu genituras ex motu syderum, et astrorum cursu metiuntur, ac iudicant futura, sive etiam praesentia, et praeterita occulta, atque ex puerorum ortu, et natali die, sive quavis alia temporum, et momentorum vanissima observatione, et notatione, de uniuscuiusque hominus statu, conditione, vitae cursu, honoribus, divitiis, sobole, salute, morte, itineribus, certaminibus, inimicitiis, carceribus, caedibus, variis discriminibus, aliisque prosperis, et adversis casibus, et eventibus praecognoscere, iudicare, et affirmare temere praesumunt, non sine magno periculo erroris, et infidelitatis; cum S. Augustinus praecipuum Ecclesiae lumen, eum, qui haec observat, qui attendit, qui in domum recipit, qui interrogat, Christianam fidem, et baptismum praevaricasse affirmet, ut illos merito Apostolus arguat, atque increpet illis verbis: Dies observatis, et menses, et tempora, et annos, timeo vos ne forte sine causa laboraverim in vobis (177a51-b15)." The text of the bull is written in extended periodic sentences. Germana Ernst conveniently prints the official contemporary Italian translation of this bull and the related one by Urban VIII (1631) in her extremely useful edition of Tommaso Campanella's Opuscoli astrologici: Come evitare il fato astrale; Apologetico; Disputa sulle bolle (Milan: Rizzoli, 2003), 255-64. I take the Latin text from Magnum bullarium romanum: bullarum, privilegiorum ac diplomatum romanorum pontificum amplissima collectio (Graz: Akademische Druck- und Verlagsanstalt, 1964-1966), vol. 4, part 4, 176-79, a photomechanical reproduction of the Roman collection of 1733-62. The text has two columns per page, which I distinguish in my citation by $a$ and $b$, as is done above with the Latin of Thomas's text.
} 
strongly rejects. Sixtus also makes clear that not only are the practitioners at fault, but their clients, too, and that anyone engaged in such practices cannot be considered a good Christian. We can also now see how Augustine's great authority is used on both sides of the debate.

Having reached this rhetorical crescendo of anti-astrological argumentation, Sixtus brings his point home concerning astrology's profoundly deleterious effects on the human soul. In the process, he explicitly mentions free will for the first time:

Therefore, these insignificant and rash men [sc. the astrologers] - to the wretched ruin of their souls, a grave scandal to the faithful, and a detriment to the Christian faith-ascribe [1] future outcomes of things (futuri rerum eventus), and [2] whatever will turn out well or badly, [3] human actions (actus humani), and finally [4] what sets out from the free will of men (ex libera hominum voluntate) to the stars and constellations, and they attribute to them the faculty, force or power, and efficacy of signifying future things (significandi futura). And being inclined in such a way to what is foreknown that in general they will not turn out otherwise, for this reason they do not hesitate to make judgments, prognostications and predictions on all these matters, to assume foreknowledge (praecognitiones) to themselves, and to sell it openly. To these, few uneducated and inexperienced people, who are too credulous of others and foolish, offer so much faith that from the rule of judgments and predictions of this sort, they believe and hope that something is certainly (certo) the case. Of which people, to be sure, both the temerity of mendacious masters and the credulity of unfortunate pupils are particularly deplorable, who either, admonished by divine letters [sc. sacred scripture], do not understand man's superiority, whom [sc. man] the heavens and constellations and the brightest stars of heaven, the sun and moon, with God disposing them in this way, do not rule but serve. For thus, Moses warned God's people to beware this error: "With your eyes raised to the heavens, do you not see the sun and moon and all the stars of heaven; and deceived by 
error, do you adore and worship what the Lord, your God, created in service to all nations which exist under heaven?" (Deuteronomy 4:19) ${ }^{72}$

Here Sixtus offers his interpretation of man's proper relation to the heavens. The stars do not rule but rather serve men, who are ontologically superior.

After issuing a series of warnings, Sixtus enumerates several groups of practitioners of divination, including geomancers, chiromancers, and necromancers (astrologers are not mentioned). He concludes the extensive introductory section by bringing astrology back into the discussion. Once again, there are striking parallels with Thomas's analysis:

A similar impiety to all those enumerated above has the same outcome, presumably because, with the deceptions and trickeries of a demon, both those who divine (divinant) and those who seek out divination (divinationem expetunt) are found to be miserably mocked and deceived [sc. by demons]. Therefore [here astrology returns], since it is proper to God (Dei proprium) to consider future events in themselves (in seipsis) before they come to be, this follows necessarily: that the astrologi and the others mentioned before, who dare to foretell (praenunciare) or foreknow (praenoscere) future things of this sort in any manner whatsoever-unless with God's revelation-unjustly and impudently assume for themselves and usurp what is God's. Thus it comes about that while what is of the Creator alone is attributed by them mistakenly to creatures, divine majesty is profoundly harmed, the integrity of the faith

\footnotetext{
72 "Hi igitur levissimi, et temerarii homines in miserandam animarum suarum ruinam, grave fidelium scandalum, et Christianae fidei detrimentum, futuros rerum eventus, et quaecumque prospere, vel adverse obventura sunt, ac actus humanos, ea denique quae ex libera hominum voluntate proficiscuntur, astris, syderibusque adscribunt, eisque eam facultatem, vim, seu virtutem, et efficaciam tribuunt significandi futura; et ad praecognita ita inclinandi, ut sic omnino, nec aliter eventura sint, atque ob eam causam de iis rebus omnibus iudicia facere, prognostica, praedictiones, et praecognitiones sibi assumere, et palam venditare non dubitant; quibus pauci rudes, et imperiti, aliisque nimis creduli, et imprudentes tantam fidem praestant, ut ex huiusmodi iudiciorum, et praedictionum praescripto, aliquid certo esse credant, aut sperent; quorum sane, et mendacium Magistrorum temeritas, et infelicium discipulorum credulitas magnopere deploranda est, qui vel divinis literis admoniti non intelligunt hominis praestantiam, cui Coeli, et Stellae, et clarissima Coeli sydera, Sol et Luna, Deo ita disponente, non imperant, sed inserviunt, sic enim Moyses populum Dei, ut hunc errorem caveret, praemonebat: ne forte elevatis oculis ad Coelum, videas Solem, et Lunam, et omnia astra Coeli, et errore deceptus adores ea, et colas, quae creavit Dominus Deus tuus in ministerium cunctis gentibus, quae sub Coelo sunt" (177b15-49).
} 
violated, and plague and death are brought into the souls redeemed by Christ's precious blood. $^{73}$

Here Sixtus refers specifically to a type of superstition discussed by Thomas-namely, idolatry - where worship due the Creator is given instead to his creatures. With the reference to in seipsis and the caveat regarding revelation, Sixtus implicitly aligns himself with Thomas's first, stronger position (T1), wholly rejecting astrological prediction of matters that can only be known in themselves. The practical implications of Sixtus's decision to reject all of judicial astrology (although he does not explicitly call it such here) appear in the bull's following two sections.

In the first, Sixtus refers explicitly to Rule IX of the Index, but he reverses its order, and in so doing puts much greater emphasis on astrology, although he recounts the contents of the rule almost precisely verbatim: ${ }^{74}$

And although already in the Rules of the Index of Prohibited Books made by the decree of the sacred general Council of Trent, this was established among other things, [IIA] that bishops should diligently oversee that books, treatises and indices of judicial astrology (astrologia iudiciaria) not be read or owned, which dare to affirm any outcome with certainty (certo) concerning [1] future contingent outcomes, [2] fortuitous occurrences, or [3] those actions which depend on human volition, [IIB] with judgments and natural observations set to the side, which have been written to assist navigation, agriculture or the medical art. [I] But take care that all books and writings of geomancy, hydromancy, chiromancy, necromancy—or those in which are contained

\footnotetext{
73 "Quorum omnium, quos supra enumeravimus consimilis impietas parem exitum habet, nimirum, quod Daemonis praestigiis, ac dolis, tum qui divinant, tum qui divinationem expetunt illusi, ac delusi miserrime reperiuntur. Itaque cum futuros eventus in seipsis considerare, antequam fiant, sit Dei proprium, illud necessario consequitur, ut Astrologi, et alii praedicti, qui huiusmodi futura praenunciare, aut praenoscere quocumque modo, nisi Deo revelante audent, iniuste, atque impudenter, quod Dei est, sibi assumant, et usurpent. Sic fit, ut dum ab eis, quod solius est Creatoris, perperam creaturis tribuitur, divina majestas graviter laedatur, fidei integritas violetur, et animabus pretioso Christi Sanguine redemptis, pestis, atque exitium importetur" (178b14-32).

${ }^{74}$ The numbers in the translation correspond to the ones indicated in the discussion of Rule IX above.
} 
sortilegia, veneficia, auguria, auspicia or incantations of the magical art-be completely rejected and abolished. ${ }^{75}$ (emphasis mine)

Sixtus here clearly and accurately repeats the strictures of Rule IX, informed by but going significantly beyond Thomas's analysis. His text thus faithfully reflects Rule IX's careful distinctions and clarifications, clearly following it and not the orientation of earlier indexes. These distinctions concerning astrology are then followed by a list of problematic types of divination, which are all called illegitimate. ${ }^{76}$

Sixtus then complains that Rule IX has not been sufficiently effective over the past 22 years:

Nevertheless, the extirpation of the aforesaid errors, seductions, offences, and abuses has not yet been provided for, such that even now, in some places and among many people, they thrive in a very curious manner, since they are uncovered every day. And very frequently, when the insidious deeds of the devil have been detected, they [sc. the places] are all full of divinations, sortilegia, and various superstitions. ${ }^{77}$

Thus, according to Sixtus, the relevant post-Tridentine laws in the Index have not proven to be sufficiently effective, and he forcefully associates astrology's heretofore legitimate practices with extremely illegitimate forms of divination.

With this anti-divinatory rhetorical conditioning and the reiteration of Rule IX as background, Sixtus then states his own official position, which I will examine in detail. He obviously intends

\footnotetext{
75 "Et licet iampridem regulis Indicis librorum prohibitorum ex decreto Sacri Generalis Tridentini Concili confecti, illud inter cetera constitutum fuerit, [IIA] ut Episcopi diligenter providerint, ne huiusmodi Astrologiae iudiciariae libri, tractatus, et indices legerentur, vel haberentur, qui de futuris contingentibus successibus, fortuitisve casibus, aut iis actionibus, quae ab humana voluntate pendent, certo aliquid eventurum affirmare audent, [II B] praemissis tamen iudiciis, et naturalibus observationibus, quae navigationis, agriculturae sive medicae artis iuvandae gratia conscripta fuissent. [1] Libros vero omnes, et scripta Geomantiae, Hydromantiae, Chiromantiae, Negromantiae, sive in quibus continentur sortilegia, veneficia, auguria, auspicia, incantationes artis magicae, prorsus reiici, et aboleri current" (178b33-52).

${ }^{76} \mathrm{He}$ neglects to mention three common practices of divination (aeromancy, pyromancy, and onomancy) for no reason that I can discern.

77 "Non tamen errorum, corruptelarum, delictorum, et abusuum praedictorum extirpationi usque adeo provisum est, quin etiam adhuc in nonnullis locis, et apud plurimos curiosius vigeant, cum valde frequenter, detectis diaboli insidiis, divinationum, sortilegiorum, et variarum superstitionum omnia plena esse in dies detegantur" (178b52-60).
} 
to tighten existing strictures against divination in general and astrology in particular in order to protect the faithful. Resorting again to a strongly anti-divinatory tone, Sixtus offers the text of his law. We should attend to how he transforms Rule IX:

We have established and command, with this perpetually valid constitution by apostolic authority, that against [A] astrologers (astrologi), mathematici, and others whomsoever who henceforth practice the art of the said judicial astrology (astrologia iudiciaria) — except in relation to agriculture, navigation and the magical art (rem Magicam [sic!] $)^{78}$ —as they make judgments (iudicia) and men's nativities, by which they dare to affirm that something will happen [1] concerning future contingent outcomes (de futuris contingentibus successibus) or [2] chance occurrences (fortuitisque casibus) or [3] actions dependent on human volition (actionibus ex humana voluntate pendentibus), even if they claim or protest that they do not affirm it [sc. the iudicium] with certainty (certo), ... ${ }^{79}$

In this first clause, if we ignore the subversive (or merely embarrassing) typographical error, we see that Sixtus preserves and protects the three natural astrological ends while striving to entirely eradicate judicial practices by removing the certainty caveat given in Rule IX. For Sixtus, then, all judicial practices are now and forevermore proscribed. Given his examples, which are a precise reiteration of those mentioned in Rule IX, it is clear that Sixtus is pushing Rule IX's significant tolerance past the relative tolerance of Thomas's second position (T2) all the way back to the significantly more restrictive regime of Thomas's first position (T1) concerning these matters.

Sixtus continues and completes this sentence by articulating more of the social levels addressed by the bull, giving a sense of the pervasive nature of the problem and its wide-ranging expression

\footnotetext{
${ }^{78}$ Surely Sixtus meant rem Medicam here. Was he the victim of a typographer's practical joke?

79 “" $[\mathrm{H}] \mathrm{ac}$ perpetuo valitura Constitutione, Apostolica auctoritate statuimus, et mandamus, ut tam contra Astrologos, Mathematicos, et alios quoscumque dictae iudiciariae Astrologiae artem, praeterquam circa agriculturam, navigationem, et rem Magicam [Medicam] in posterum exercentes, ut facientes iudicia, et nativitates hominum, quibus de futuris contingentibus successibus, fortuitisque casibus, aut actionibus ex humana voluntate pendentibus aliquid eventurum affirmare audent, etiam si id se non certo affirmare asserant, aut protestentur (179a14-27),”
} 
throughout society, among both sexes, and addresses those who study, practice, or otherwise participate in such activities: ${ }^{80}$

... and against [B] others of either sex, [1] who either practice, profess, and teach or learn the aforesaid condemned, vain, false, and pernicious arts or sciences of divining (divinandi artes sive scientiae) or [2] who make illicit divinations of this sort [sc. excluding action taken for the natural ends just mentioned], sortileges, superstitions, veneficia, incantations, and the aforementioned detestable and wicked crimes, as said before, [3] or participate in them in any manner, of whatever dignity, degree, or condition they are, let both [a] bishops and prelates, superiors and the other ordinaries of places, and [b] Inquisitors of depraved heresy of people everywhere-even if in most of these cases they did not proceed against them before or they were unable to proceed-let them inquire diligently and proceed, and let them turn toward them severely with canonical and other penalties by their judgment. ${ }^{81}$

As is evident, Sixtus expresses no tolerance at all for judicial astrology, no matter who is practicing it, hurling all astrologers into the same demon-infested waters as those who practice the other nefarious types of divinatory activities.

Sixtus ends this section by making his prohibitive point one last time before casting it all in the proper legal formulae:

Prohibiting each and every book, work, and treatise of this sort of judicial astrology (iudiciaria astrologia), geomancy, hydromancy, pyromancy, onomancy, chiromancy, necromancy, magical art, or those in which sortilegia,

\footnotetext{
${ }^{80}$ For some of the rich evidence of clerical participation in such practices, see Richard Kieckeffer, Magic in the Middle Ages (Cambridge: Cambridge University Press, 1989), and now Sophie Page, Magic in the Cloisters: Pious Motives, Illicit Interests and Occult Approaches to the Medieval Universe (University Park: Pennsylvania State University Press, 2013), and, for a later period, Lynn Mollenauer, Strange Revelations: Magic, Poison, and Sacrilege in Louis XIV's France (University Park: Pennsylvania State University Press, 2006).

81 “[Q]uam contra alios utriusque sexus, qui supradictas damnatas, vanas, fallaces, et perniciosas divinandi artes, sive scientias exercent, profitentur, et docent, aut discunt, quive huiusmodi illicitas divinationes, sortilegia, superstitiones, veneficia, incantationes, ac praemissa detestanda scelera, et delicta, ut praefertur, faciunt, aut in eis se quomodolibet intromittunt, cuiuscumque dignitatis, gradus, et conditionis existant, tam Episcopi, et Praelati, Superiores, ac alii Ordinarii locorum, quam Inquisitores haereticae pravitatis ubique gentium deputati, etiamsi in plerisque ex his casibus antea non procedebant, aut procedere non valebant, diligentius inquirant, et procedant, atque in eos severius canonicis poenis, et aliis eorum arbitrio animadvertant" (179a27-45).
} 
veneficia, auguria, auspicia, execrable incantations, and superstitions are contained, and as interdicted above in the recalled Index under the censures and penalties contained in it. ${ }^{82}$

The rest of the bull discusses legal matters, in particular the proper and authoritative establishment and promulgation of the law.

Sixtus thus dramatically and unambiguously overturns the moderation of Rule IX. Any practice of judicial astrology is henceforth outlawed, whether certainty is claimed or not. In contrast to the tolerance expressed by Rule IX, all astrological judgments and nativities that make predictions concerning future contingent or chance occurrences or those dependent on human volition are now illegal and should be vehemently prosecuted, even if such practices had hitherto been ignored. Unless it serves a medical, agricultural, or navigational end, all of astrology is now subsumed under the illicit and demonic brand of divination, following Thomas's first, stricter position (T1) - as well as Pico's passionate rebranding efforts - thereby sharply delimiting astrology's room for legitimate activity. By aggressively and uncompromisingly collapsing Thomas's distinctions and those found in Rule IX of the Index, Sixtus vigorously restricted astrology's activity up and down the social ladder.

\section{Conclusion}

A fundamental tension concerning astrology thus emerges from comparing Rule IX of the official 1564 Index of Prohibited Books with the fundamentally anti-astrological as well as antidivinatory papal bulls of Sixtus V (1586) and later Urban VIII (1631). All of these are legally binding documents that articulate the relationship of astrology to divination. The crux of the tension is in the claim of certainty for what was coming to be called judicial astrology and the implications for the legitimate practice of astrology. Tangible expression of this tension is visible in the immediately ensuing debates in the two Roman Congregations of the Holy Office and of the Index, where, after 1586, numerous inquiries for official clarification were submitted to resolve the obvious discrepancies between Rule IX of the Index and the 1586 bull, which,

\footnotetext{
82 "Prohibentes omnes, et singulos libros, opera, et tractatus huiusmodi iudiciariae Astrologiae, Geomantiae, Hydromantiae, Pyromantiae, Onomantiae, Chiromantiae, Necromantiae, Artis Magicae, aut in quibus sortilegia, veneficia, auguria, auspicia, execrabiles incantationes, ac superstitiones continentur, ac ut supra in memorato Indice interdictos sub censuris et poenis in eo contentis" (179a).
} 
however contradictory, were both legally binding. ${ }^{83}$ In the end, the forces of moderation prevailed and re-established Rule IX in its 1564 formulation in the official 1596 and all subsequent indexes of prohibited books. ${ }^{84}$ In the wake of the colorful Orazio Morandi affair, however, Urban VIII attempted - once again without success - to reassert Sixtus V's more extreme position with his own bull Inscrutabilis (1631). ${ }^{85}$

We can thus see a three-fold movement: Thomas made a fundamental distinction between legitimate and illegitimate prognosticatory practices based on whether any foreknowledge or prediction of the future were derived from a legitimate causal basis or not. In the earlier and stronger statement of his position (Summa theologiae 95.1 [T1]), foreknowledge or prediction of infrequent chance occurrences or of human actions based on free will are both described as divination and outlawed. Nevertheless, his text almost immediately mitigates both the force and clarity of this authoritative statement by admitting that most people normally follow their bodily inclinations, all of which are deeply informed by celestial influences. In fact, in his modified second position (Summa theologiae 95.5 ad 2 [T2]), Thomas effectively opens the door for a central feature of what came to be called judicial astrology, namely, the prediction of actions based on the choices of a free will, but only if certainty is not claimed. The significant ambiguity arising from Thomas's authoritative but contradictory pronouncements allowed for both 16th century positions.

Following Thomas's second, more tolerant position (T2), Rule IX of the 1564 Index further expanded the domain of astrological activity that had already been considered by Thomas as legitimate to explicitly include future contingent or chance events, as well as actions based on free will, as long as the predictions did not claim certainty. This implicitly aligns these practices - which Sixtus identified as nativities, elections, and interrogations-with those practices Thomas explicitly allowed as conjectural (namely, revolutions) because they are based on causal analysis. Rule IX explicitly terms this area "judicial astrology" (astrologia iudiciaria). Rule IX also protects astrological practices that subserve the legitimate ends of agriculture, navigation, and medicine, which we may justifiably call "natural" ends, and thus refer to as

\footnotetext{
${ }^{83}$ For the actual discussions, see Ugo Baldini and Leen Spruit, eds., Catholic Church and Modern Science: Documents from the Archives of the Roman Congregations of the Holy Office and the Index, vol. 1 of 4 (Rome: Libreria Editrice Vaticana, 2009-). I hope to explore these issues further in a follow-up article.

${ }^{84}$ This can be clearly seen in the text of the 1596 Index, reprinted in facsimile in ILI, IX, 922.

${ }^{85}$ See Ernst, "Della Bolla." I discuss this material in more depth in Rutkin, Sapientia astrologica, vol. 3.
} 
"natural astrology." The third movement, then, consists of Sixtus V's taking the controversial "judicial" practices - those relating to contingent or chance events and to actions based on free will, whether they claim certainty or not—and casting them all into the illegitimate and demonic snake pit of superstitious divinatory practices, thus siding with the first more restrictive statement of Thomas's position (T1). Regardless, Sixtus, too, safeguarded the three legitimate natural ends and thus did not by any means reject all of astrology.

In the distinction between natural and judicial astrology, we encounter those practices that Sixtus identifies as nativities, elections, and interrogations within the purview of judicial astrology, insofar as they are concerned with the foreknowledge and prediction of contingent and chance events and of actions based on free will. On the other hand, astrological practice that is intended to support medicine, navigation, and agriculture - and which for the most part (but not only) derives from natural observations (whatever precisely these may be) - fall into the domain of natural astrology. It thus seems that the prognosticatory object and end toward which a given astrological practice is directed determines its affiliation and legitimacy more than the type of practice itself. For example, in addition to revolutions, medicine also regularly used nativities, elections, and interrogations.

\section{Bibliography}

Aquinas, Thomas. Summa theologiae. Opera omnia, vol. 9. Rome: Ex Typographia Polyglotta S.C. de Propaganda Fide, 1897.

Aquinas, Thomas. De iudiciis astrorum. Opera omnia, vol. 43. Rome: Ex Typographia Polyglotta S.C. de Propaganda Fide, 1976.

Aquinas, Thomas. Summa theologiae. Latin text and English Translation, vol. 40. London: Blackfriars, 1968.

Aquinas, Thomas. Summa theologiae: Latin Text and English Translation, Introductions, Notes, Appendices and Glossaries, vol. 40, Superstition and Irreverence, trans. and ed. Thomas Franklin O'Meara and Michael John Duffy (London: Blackfriars, 1968),

Bezza, Giuseppe. Arcana mundi: Antologia del pensiero astrologico antico. 2 vols. Milan: Rizzoli, 1995.

Boudet, Jean-Patrice. Entre science et nigromance: astrologie, divination et magie dans l'occident médiéval, XIIe-XVe siècle. Paris: Publications de la Sorbonne, 2006.

Boyle, Leonard E. O.P. "The Setting of the Summa theologiae of Saint Thomas." In Facing History: A Different Saint Thomas, 65-91. Louvain-la-Neuve: Fédération Internationale des Instituts d'Études Médiévales, 2000. 
Burnett, Charles. "Astrology.” In Medieval Latin: An Introduction and Bibliographical Guide, edited by F.A.C. Mantello and A.G. Rigg, 369-82. Washington, DC: Catholic University of America Press, 1996.

. "On Judging and Doing in Arabic and Latin Texts on Astrology and Divination." In The Impact of Arabic Sciences in Europe and Asia, edited by Agostino Paravicini Bagliani, 311. Florence: Sismel Edizioni del Galluzzo, 2016.

. "Talismans: Magic as Science? Necromancy among the Seven Liberal Arts." In Magic and Divination in the Middle Ages: Texts and Techniques in the Islamic and Christian Worlds, 1-15. Aldershot: Ashgate Variorum, 1996.

Campanella, Tommaso. Opuscoli astrologici: Come evitare il fato astrale; Apologetico; Disputa sulle bolle. Edited by Germana Ernst. Milan: Rizzoli, 2003.

Baldini, Ugo, and Leen Spruit, eds. Catholic Church and Modern Science: Documents from the Archives of the Roman Congregations of the Holy Office and the Index. Vol. 1, SixteenthCentury Documents, vol. 1, 4 tomes. Rome: Libreria Editrice Vaticana, 2009.

Ernst, Germana. 'Della Bolla 'Coeli et terrae' all' 'Inscrutabilis': 1'astrologia tra religione, natura e politica nell'età della Controriforma." In Religione, ragione e natura: Ricerche su Tommaso Campanella e il tardo Rinascimento, 255-79. Milan: FrancoAngeli, 1991.

Feke, Jacqueline. Ptolemy's Philosophy: Mathematics as a Way of Life. Princeton, NJ: Princeton University Press, 2018.

Fidora, Alexander. "Signs vs. Causes? An Epistemological Approach to Prognosis in the Latin Middle Ages." Tópicos, Revista de Filosofía 47 (2014): 9-23.

Flint, Valerie I. J. The Rise of Magic in Early Medieval Europe. Princeton, NJ: Princeton University Press, 1991.

Grendler, Paul F. The Roman Inquisition and the Venetian Press, 1540-1605. Princeton, NJ: Princeton University Press, 1977.

Harmening, Dieter. Superstitio: Überlieferungs- und theoriegeschichtliche Untersuchungen zur kirchlich-theologischen Aberglaubensliteratur des Mittelalters. Berlin: Erich Schmidt Verlag, 1979.

Index des livres interdits (ILI), vol. VIII, Index de Rome 1557, 1559, 1564: Les premiers index romains et l'index du concile de Trente, edited by J. M. de Bujanda. Sherbrooke, Québec: Centre d'études de la Renaissance, 1990.

Kieckeffer, Richard. Magic in the Middle Ages. Cambridge: Cambridge University Press, 1989. Klingshirn, William E. "Divination and the Disciplines of Knowledge according to Augustine." In Augustine and the Disciplines: From Cassiciacum to Confessions, edited by Karla Pollmann and Mark Vessey, 113-40. Oxford: Oxford University Press, 2005. . “Isidore of Seville's Taxonomy of Magicians and Diviners." Traditio 58 (2003): 59-90.

Litt, Thomas. Les corps célestes dans l'univers de Saint Thomas d'Aquin. Louvain: Publications Universitaires, 1963.

Magnum bullarium romanum: bullarum, privilegiorum ac diplomatum romanorum pontificum amplissima collectio. Graz: Akademische Druck- und Verlagsanstalt, 1964-1966.

Mollenauer, Lynn. Strange Revelations: Magic, Poison, and Sacrilege in Louis XIV's France. University Park: Pennsylvania State University Press, 2006.

Page, Sophie. Magic in the Cloisters: Pious Motives, Illicit Interests and Occult Approaches to the Medieval Universe. University Park: Pennsylvania State University Press, 2013. 
Park, Katharine. "Observation in the Margins, 500-1500." In Histories of Scientific Observation, edited by Lorraine Daston and Elizabeth Lunbeck, 15-44. Chicago: University of Chicago Press, 2011.

Peters, Edward. The Magician, The Witch, and the Law. Philadelphia: University of Pennsylvania Press, 1978.

. "The Medieval Church and State on Superstition, Magic and Witchcraft: From Augustine to the Sixteenth Century." In Witchcraft and Magic in Europe: The Middle Ages, edited by Bengt Ankarloo and Stuart Clark, 173-245. Philadelphia: University of Pennsylvania Press, 2002.

Pico della Mirandola, Giovanni. Disputationes adversus astrologiam divinatricem, edited by Eugenio Garin, 2 vols. Florence: Vallecchi, 1946-52 (Turin: Nino Aragno, 2004).

Poppi, Antonino. Cremonini, Galilei e gli inquisitori del santo a Padova. Padua, Italy: Centro Studi Antoniani, 1993.

Porro, Pasquale. "Lex necessitatis vel contingentiae: Necessità, contingenza e provvidenza nell'universo di Tommaso d'Aquino." Revue des Sciences Philosophiques et Theologiques 96 (2012): 401-49.

Rutkin, H. Darrel. "Astrologia e divinazione in Tommaso d'Aquino." Translated by Chiara Petrolini. In Il linguaggio dei cieli: astri e simboli nel Rinascimento, edited by Germana Ernst and Guido Giglioni, 23-37. Frecce: Carocci Editore, 2012.

"Astrology." In The Cambridge History of Science, Vol. 3: Early Modern Science, edited by Lorraine Daston and Katharine Park, 541-61. Cambridge: Cambridge University Press, 2006.

. "Astrology and Magic." In A Companion to Albert the Great: Theology, Philosophy and the Sciences, edited by Irven M. Resnick, 451-505. Leiden, Germany: Brill, 2013.

. "Galileo Astrologer: Astrology and Mathematical Practice in the Late-Sixteenth and Early-Seventeenth Centuries." GALILAEANA: Journal of Galilean Studies 2 (2005): $107-43$.

. "How to Accurately Account for Astrology's Marginalization in the History of Science and Culture: The Essential Importance of an Interpretive Framework." Early Science and Medicine 23 (2018): 217-43.

. "The Mysteries of Attraction: Giovanni Pico della Mirandola, Astrology and Desire." Studies in History and Philosophy of Biological and Biomedical Sciences 41 (2010): 11724.

. “Optimus malorum: Giovanni Pico della Mirandola's Complex and Highly Interested Use of Ptolemy in the Disputationes adversus astrologiam divinatricem (1496), A Preliminary Survey." Presented at the Conference Ptolemaeus Arabus et Latinus, London, November 2015.

. "The Physics and Metaphysics of Talismans (Imagines Astronomicae): A Case Study in (Neo)Platonism, Aristotelianism and the Esoteric Tradition." In Platonismus und Esoterik in Byzantinischem Mittelalter und Italienischer Renaissance, edited by Helmut Seng, 149-73. Heidelberg, Germany: Universitätsverlag Winter, 2013.

. Sapientia Astrologica: Astrology, Magic and Natural Knowledge, ca. 1250-1800, to be published in the series, "Archimedes: New Studies in the History and Philosophy of Science and Technology," edited by Jed Z. Buchwald. Dordrecht: Springer, 3 vols. Volume 1, "Medieval Structures (1250-1500): Conceptual, Institutional, Socio-Political, Theologico-Religious and Cultural," 2019. 
. "Understanding the History of Astrology Accurately: Methodological Reflections on Terminology and Anachronism." Philosophical Readings 7 (2015): 42-54.

. "The Use and Abuse of Ptolemy's Tetrabiblos in Renaissance and Early Modern Europe: Two Case Studies (Giovanni Pico della Mirandola and Filippo Fantoni).” In Ptolemy in Perspective: Use and Criticism of his Work from Antiquity to the Nineteenth Century, edited by Alexander Jones, 135-149. Dordrecht, Germany: Springer, 2010.

Savonarola, Girolamo. Contro gli astrologi, edited by Claudio Gigante. Rome: Salerno Editrice, 2000.

Schabel, Christopher D. Theology at Paris, 1316-1345: Peter Aureol and the Problem of Divine Foreknowledge and Future Contingents. Aldershot, UK: Ashgate, 2000.

Thomas, Keith. Religion and the Decline of Magic. New York: Scribners, 1971.

Torrell, Jean-Pierre. Saint Thomas Aquinas, Vol. 1, The Person and His Work. Translated by Robert Royal. Washington, DC: The Catholic University of America Press, 1996.

Verardi, Donato. 'Les Enseignements sur 1'Astrologie d'Augustin d'Hippone et de Thomas d'Aquin dans la Bulle Coeli et Terrae de Sixte V." Revue des Sciences Philosophiques et Théologiques 101 (2017): 125-33.

Weill-Parot, Nicolas. Les «images astrologiques» au moyen âge et à renaissance: spéculations intellectuelles et pratiques magiques (XIIe-XVe siècle). Paris: Champion, 2002.

Willis, Roy, and Patrick Curry. Astrology, Science and Culture: Pulling Down the Moon. Oxford: Berg, 2004.

Zambelli, Paola. The Speculum astronomiae and its Enigma: Astrology, Theology and Science in Albertus Magnus and his Contemporaries. Dordrecht, Germany: Kluwer, 1992. 